\title{
Copper-Catalyzed Semihydrogenation of Alkynes to Z-Alkenes
}

\author{
Kazuhiko Semba*a \\ Ryohei Kameyama ${ }^{a}$ \\ Yoshiaki Nakao*a,b \\ a Department of Material Chemistry, Graduate School of Engineering, \\ Kyoto University, Nishikyo-Ku, Kyoto 615-8510, Japan \\ semba.kazuhiko.5n@kyoto-u.ac.jp \\ nakao.yoshiaki.8n@kyoto-u.ac.jp \\ b CREST, Japan Science and Technology Agency (JST), 4-1-8 Honcho, \\ Kawaguchi, Saitama 332-0012, Japan
}

Received: 16.12.2014

Accepted after revision: 20.01.2015

Published online: 26.01 .2015

DOI: 10.1055/s-0034-1379896; Art ID: st-2014-r1032-c

Abstract Copper-catalyzed semihydrogenation of internal alkynes has been developed. The reaction proceeds under an atmosphere of hydrogen $(5 \mathrm{~atm})$ at $100{ }^{\circ} \mathrm{C}$ in the presence of a readily available $\left[\left(\mathrm{PPh}_{3}\right) \mathrm{CuCl}\right]_{4}$ catalyst to give various Z-alkenes stereoselectively.

Key words alkynes, alkenes, catalysis, copper, hydrogenation

Much attention has been paid to develop copper-catalyzed reduction of unsaturated compounds such as carbonyls, imines, Michael acceptors, and alkynes due to low cost and abundance of copper as well as high chemo-, regio-, and stereoselectivities associated with copper catalysis., ${ }^{1,2}$ Usually, hydrosilanes are employed as a stoichiometric reducing reagent. In contrast, copper-catalyzed reduction using $\mathrm{H}_{2}$ (hydrogenation) is rare, although it is more atomefficient than the use of hydrosilanes. Hydrogenation of polar multiple bonds such as aldehydes, ketones, and Michael acceptors has been relatively well-studied with copper catalysis, ${ }^{3}$ whereas that of nonpolar multiple bonds such as alkynes is limited. To the best of our knowledge, $\mathrm{Cu}_{2} \mathrm{O}$-catalyzed semihydrogenation of terminal alkynes under an atmosphere of $\mathrm{H}_{2}(20 \mathrm{~atm})$ has been the only precedent. ${ }^{4}$

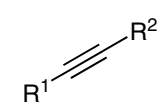 \\ $\mathrm{R}^{1}=$ aryl, alkyl \\ $\mathrm{R}^{2}=$ aryl, alkyl
}<smiles>[R]/C=C\[R]</smiles>

76-99\% yield $>20: 1$ selectivity

Semihydrogenation of internal alkynes is an efficient method to prepare $Z$-alkenes, which are versatile building blocks in organic synthesis and often found in biologically active compounds. A variety of heterogeneous catalysts have been developed for this transformation. ${ }^{5}$ Especially, the Lindlar catalyst is a well-established and effective catalyst for semihydrogenation of alkynes. ${ }^{6}$ Nevertheless, it often suffers from $Z / E$ isomerization, shift of double bonds, and overhydrogenation to give alkanes. Thus, uptake of $\mathrm{H}_{2}$ must be accurately monitored to control the hydrogenation. To overcome such difficulties, homogeneous catalysts such as rhodium, chromium, palladium, ruthenium, vanadium, and niobium have been developed. ${ }^{7}$ Here, we report that $\left[\left(\mathrm{PPh}_{3}\right) \mathrm{CuCl}\right]_{4},{ }^{8}$ a readily available copper complex, efficiently catalyzes semihydrogenation of internal alkynes to give $Z$-alkenes in a highly stereoselective manner under an atmosphere of $\mathrm{H}_{2}$ (5 atm).

First, we optimized the reaction conditions employing 1-phenyl-1-hexyne (1a) as a model substrate (Table 1). After screening a variety of reaction parameters, semihydrogenation of 1a gave $(Z)$-1-phenyl-1-hexene $[(Z)$-2a] selectively in high yield without formation of $(E)$-1-phenyl-1hexene $[(E)-\mathbf{2 a}]$ and hexylbenzene $(\mathbf{3 a})$ under the standard conditions: $\left[\left(\mathrm{PPh}_{3}\right) \mathrm{CuCl}\right]_{4}(2.0 \mathrm{~mol} \% / \mathrm{Cu}), \mathrm{LiOt}-\mathrm{Bu}(50 \mathrm{~mol} \%)$, and $i-\mathrm{PrOH}(1.0 \mathrm{mmol})$ in toluene at $100{ }^{\circ} \mathrm{C}$ for 3 hours under an atmosphere of $\mathrm{H}_{2}(5 \mathrm{~atm})$ (Table 1, entry 1$)$.

Table 1 Semihydrogenation of $\mathbf{1}$ a with Various Copper Catalysts

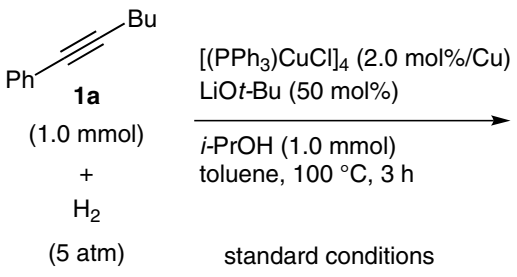

\begin{tabular}{|c|c|c|c|c|}
\hline Entry & Variation from the standard conditions & Conv. of 1a $(\%)^{a}$ & Yield of $(Z)-\mathbf{2 a}+(E)-\mathbf{2} \mathbf{a}+\mathbf{3 a}(\%)^{b}$ & Ratio of $(Z)-2 \mathbf{a} /(E)-2 \mathrm{a} / 3 \mathbf{a}(\%)^{\mathrm{b}}$ \\
\hline 1 & none & $>99$ & $99(80)^{c}$ & $99:<1:<1$ \\
\hline 2 & run for $12 \mathrm{~h}$ & $>99$ & 95 & $94: 2: 4$ \\
\hline 3 & $\mathrm{CuCl} / \mathrm{Ph}_{3} \mathrm{P}$ instead of $\left[\left(\mathrm{PPh}_{3}\right) \mathrm{CuCl}\right]_{4}$ & $>99$ & 95 & $99:<1:<1$ \\
\hline 4 & $\mathrm{CuCl} / \mathrm{P}(\mathrm{o} \text {-tol })_{3}$ instead of $\left[\left(\mathrm{PPh}_{3}\right) \mathrm{CuCl}\right]_{4}$ & $<5$ & - & - \\
\hline
\end{tabular}


Table 1 (continued)

\begin{tabular}{lllll}
\hline Entry & Variation from the standard conditions & Conv. of 1a (\%) & Yield of $(Z)-\mathbf{2 a}+(E)-\mathbf{2 a}+\mathbf{3 a}(\%)^{\mathrm{b}}$ & Ratio of $(Z)-\mathbf{2 a} /(E)-\mathbf{2 a} / \mathbf{3 a}(\%)^{\mathrm{b}}$ \\
\hline 5 & $\mathrm{CuCl} / \mathrm{PCy}_{3}$ instead of $\left[\left(\mathrm{PPh}_{3}\right) \mathrm{CuCl}_{4}\right.$ & $>99$ & 90 & $54: 4: 42$ \\
6 & $\mathrm{CuCl}$ instead of $\left[\left(\mathrm{PPh}_{3}\right) \mathrm{CuCl}_{4}\right.$ & $<5$ & - & - \\
7 & without $\left[\left(\mathrm{PPh}_{3}\right) \mathrm{CuCl}_{4}\right.$ & $<5$ & - & - \\
8 & without $\mathrm{LiOt}-\mathrm{Bu}$ & $<5$ & - & - \\
9 & without $i-\mathrm{PrOH}$ & $<5$ & - & - \\
10 & under $\mathrm{N}_{2}$ instead of $\mathrm{H}_{2}$ & $<5$ & - & - \\
11 & under $\mathrm{H}_{2}(1.0 \mathrm{~atm})$ & $<5$ & - & - \\
12 & $\mathrm{Cu}_{2} \mathrm{O}$ instead of $\left[(\mathrm{PPh})_{3} \mathrm{CuCl}\right]_{4}$, LiOt-Bu, and $i-\mathrm{PrOH}$ & $<5$ & - & - \\
\hline
\end{tabular}

${ }^{\text {a }}$ Determined by GC analysis with $n$-tridecane as an internal standard.

${ }^{b}$ Determined by ${ }^{1} \mathrm{H}$ NMR analysis with 1,3,5-trimethoxybenzene as an internal standard.

c Isolated yield.

Notably, the selectivity is better than that reported using the Lindlar catalyst $\{(Z)-\mathbf{2} \mathbf{a} /[(Z)-\mathbf{2} \mathbf{a}+(E)-\mathbf{2} \mathbf{a}+\mathbf{3 a}]=$ $91 \%\}{ }^{6 d}$ Compound ( $Z$ )-2a was isolated in $80 \%$ yield after medium-pressure column chromatography on silica gel (Table 1 , entry 1 ). Prolonging the reaction time to 12 hours slightly decreased the selectivity (Table 1 , entry 2). $\left[\left(\mathrm{PPh}_{3}\right) \mathrm{CuCl}\right]_{4}$ generated in situ from $\mathrm{CuCl}$ and $\mathrm{Ph}_{3} \mathrm{P}$ showed reactivity comparable to an isolated one (Table 1 , entry 3 ). $\mathrm{CuBr}$ was similarly effective as $\mathrm{CuCl}$. In contrast, other copper(I) salts such as CuI, CuOAc, and CuCN showed activity far less than $\mathrm{CuCl}$. The effects of phosphine ligands are summarized in entries 4-6 (Table 1 ). The hydrogenation did not proceed with tri(o-tolyl)phosphine $\left[\mathrm{P}(0 \text {-tol })_{3}\right]$ as a ligand or without any ligands (Table 1 , entries 4 and 6 ). In the case of tricyclohexylphosphine $\left(\mathrm{PC}_{3}\right)$, a considerable amount of $\mathbf{3 a}$ was observed (Table 1 , entry 5 ). When the reactions were performed in the absence of $\left[\left(\mathrm{PPh}_{3}\right) \mathrm{CuCl}\right]_{4}, \mathrm{LiOt}-\mathrm{Bu}$, or $i-\mathrm{PrOH}$, no products were obtained (Table 1 , entries 7-9). The reaction did not proceed under an $\mathrm{N}_{2}$ atmosphere instead of $\mathrm{H}_{2}$ (Table 1 , entry 10), indicating that $i$-PrOH did not act as a hydride source. Under an atmosphere of $\mathrm{H}_{2}$ (1.0 atm), the products were not formed (Table 1 , entry 11 ). $\mathrm{Cu}_{2} \mathrm{O}$, which was reported to serve as a catalyst for semihydrogenation of terminal alkynes, ${ }^{4}$ was ineffective under the present reaction conditions (Table 1, entry 12). Even in the presence of $\mathrm{Ph}_{3} \mathrm{P}$, $\mathrm{LiOt}-\mathrm{Bu}$, and $i-\mathrm{PrOH}, \mathrm{Cu}_{2} \mathrm{O}$ was not a good catalyst.

The scope of substrates was investigated under the optimized reaction conditions (Table 2$).{ }^{9}$ In the case of 1 -phenyl-1-propyne (1b), (Z)-1-phenyl-1-propene [(Z)-2b] was obtained in high yield with a small amount of $(E)-1$-phenyl1-propene $[(E)-\mathbf{2 b}]$ and propylbenzene (3b) (Table 2, entry $1)$. The reduction of 1-phenyl-2-trimethylsilylacetylene (1c) did not proceed (Table 2, entry 2). Diphenylacetylene derivatives 1d-g were efficiently semihydrogenated to give the corresponding $Z$-alkenes (Table 2, entries 3-6). Electron-donating and electron-withdrawing substituents on the phenyl group did not affect the yields and selectivities
(Table 2, entries 4-6). The catalytic system was also effective for semihydrogenation of aliphatic alkynes $\mathbf{1 h}$ and $\mathbf{1 i}$, giving the corresponding $Z$-alkenes $(Z)-\mathbf{2 h}$ and $(Z)-\mathbf{2} \mathbf{i}$ selectively (Table 2, entries 7 and 8). On the other hand, ynoate $\mathbf{1 j}$ and terminal alkyne 1k were not competent substrates. The reaction of $\mathbf{1} \mathbf{j}$ afforded a complex mixture (Table 2 , entry 9), whereas $\mathbf{1 k}$ was not converted at all under the present conditions (Table 2, entry 10). With 5,7-dodecadiyne (11), (Z)-5-dodecene was obtained selectively (Table 2, entry 11).

A plausible reaction mechanism is depicted in Scheme 1. Copper hydride $\mathbf{5}$ is generated from heterolytic cleavage of $\mathrm{H}_{2}$ by copper alkoxide 4 (step a). ${ }^{10}$ According to the literature, syn addition of $\mathbf{5}$ across an alkyne gives alkenyl copper $\mathbf{6}$ in a stereoselective manner (step b). ${ }^{11}$ Compound $\mathbf{6}$ is protonated by alcohol to afford (Z)-2 and regenerate 4 (step c). ${ }^{12}$ To gain insights into the proposed reaction mechanism, semihydrogenation of $\mathbf{1 a}$ was performed using $i$-PrOD

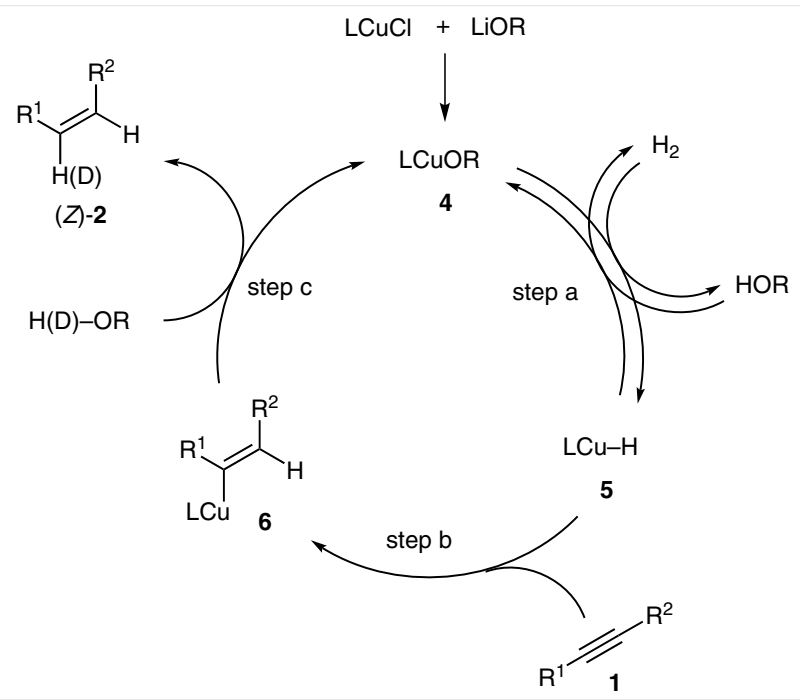

Scheme 1 A plausible reaction mechanism 
Table 2 Semihydrogenation of Various Alkynes 1

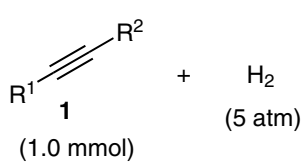

Alkyne

$\left[\left(\mathrm{PPh}_{3}\right) \mathrm{CuCl}\right]_{4}(2.0 \mathrm{~mol} \% / \mathrm{Cu})$ $\mathrm{LiOt}$-Bu $(50 \mathrm{~mol} \%)$

i-PrOH (1.0 mmol)

toluene, $100{ }^{\circ} \mathrm{C}, 3 \mathrm{~h}$

Conv. of 1 (\%)

$>99$

$96: 2: 2$

1 b<smiles>CSC#Cc1ccccc1</smiles>

$<5$<smiles>[R]c1ccc(C#Cc2ccc([Z7])cc2)cc1</smiles>

$3^{d}$

4

5

$6^{\mathrm{e}, \mathrm{f}}$

7

8

$$
\mathrm{R}^{1}=\mathrm{R}^{2}=\mathrm{H}(\mathbf{1 d})
$$$$
\mathrm{R}^{1}=\mathrm{R}^{2}=\mathrm{Me}(\mathbf{1 e})
$$$$
R^{1}=R^{2}=F(\mathbf{1 f})
$$$$
\mathrm{R}^{1}=\mathrm{C}(\mathrm{O}) \mathrm{O} i-\mathrm{Pr}, \mathrm{R}^{2}=\mathrm{H}(\mathbf{1 g})
$$<smiles>C#Cc1ccccc1</smiles>

$1 \mathrm{~h}$<smiles>CCC#CC(C)(C)Cl</smiles>

9<smiles>COC(=O)C#CCc1ccccc1</smiles>

$$
\text { 1j }
$$

10

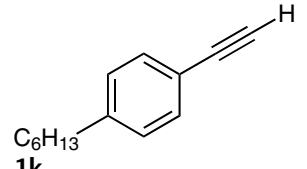

$$
1 \mathbf{k}
$$

$11^{f}$

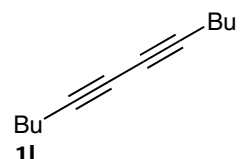

$>99$

96:3:1

$98:<1: 2$

98:1:1

$>99:<1:<1$

$>99:<1:<1$

76

11

a Determined by GC analysis with $n$-tridecane as an internal standard.

${ }^{\mathrm{b}}$ Isolated yield. Yields determined by ${ }^{1} \mathrm{H}$ NMR analysis with 1,3,5-trimethoxybenzene as an internal standard are given in parentheses.

c Determined by ${ }^{1} \mathrm{H}$ NMR analysis of a crude product.

Run at $60^{\circ} \mathrm{C}$ for $3 \mathrm{~h}$.

e Run at $80^{\circ} \mathrm{C}$ for $3 \mathrm{~h}$.

${ }^{f}$ Run in 0.30 mmol scale.

$g(Z)$-5-Dodecene was obtained selectively. 
(Scheme 2). Monodeuterated alkene (Z)-2a- $d_{1}$ was obtained regioselectively albeit with low deuterium incorporation. This result supports that $i$-PrOH serves as a source of hydrogen and that the addition of copper hydride $\mathbf{5}$ across $\mathbf{1 a}$ (step b) proceeds regioselectively. Reversibility of step a should be responsible for contamination of $i$-PrOH under the reaction conditions of Scheme 2 and thus the observed low deuterium content in $(Z)-\mathbf{2 a}-d_{1} \cdot{ }^{13}$

$$
\begin{aligned}
& { }_{\mathrm{LiOt}-\mathrm{Bu}(50 \mathrm{~mol} \%)}^{\mathrm{Bu}} \underbrace{}_{\left[\left(\mathrm{PPh}_{3}\right) \mathrm{CuCl}_{4}(2.0 \mathrm{~mol} / \mathrm{Cu})\right.} \\
& (1.0 \mathrm{mmol}) \\
& \text { toluene, } 100^{\circ} \mathrm{C}, 3 \mathrm{~h} \\
& \mathrm{H}_{2} \\
& \text { (5 atm) } \\
& \left.\right|_{D(H)} ^{D(H)}(21 \% \mathrm{D}) \\
& (Z)-2 \mathbf{a}-d_{1} \\
& 96 \% \text { by NMR }
\end{aligned}
$$

Scheme 2

In conclusion, we have established the copper-catalyzed semihydrogenation of internal alkynes. The present transformation is catalyzed by a readily available copper complex under an atmosphere of $\mathrm{H}_{2}$ (5 atm), giving $Z$-alkenes in high yields and selectivities. This simple catalytic system employing inexpensive metal catalyst can be an alternative to known protocols using a noble-metal catalyst such as the Lindlar catalyst.

\section{Acknowledgment}

This work was supported by a Grant-in-Aid for Young Scientists (B) (26810058) from MEXT and the Japan Science and Technology Corporation (CREST, 'Establishment of Molecular Technology towards the Creation of New Functions' Area).

\section{Supporting Information}

Supporting information for this article is available online at http://dx.doi.org/10.1055/s-0034-1379896.

\section{References and Notes}

(1) (a) For reviews on copper-catalyzed reduction of carbonyl compounds and Michael acceptors, see: Rendler, S.; Oestreich, M. Angew. Chem. Int. Ed. 2007, 46, 498; and references cited therein. (b) Díez-González, S.; Nolan, S. P. Acc. Chem. Res. 2008, 41, 349; and references cited therein. (c) Deutsch, C.; Krause, N.; Lipshutz, B. H. Chem. Rev. 2008, 108, 2916; and references cited therein. (d) Lipshutz, B. H. Synlett 2009, 509; and references cited therein.

(2) For references on copper-catalyzed semireduction of alkynes, see: (a) Semba, K.; Fujihara, T.; Xu, T.; Terao, J.; Tsuji, Y. Adv. Synth. Catal. 2012, 354, 1542. (b) Whittaker, A. M.; Lalic, G. Org. Lett. 2013, 15, 1112. (c) Wang, G.-H.; Bin, H.-Y.; Sun, M.; Chen, S.-W.; Liu, J.-H.; Zhong, C.-M. Tetrahedron 2014, 70, 2175. (d) Cao, H.; Chen, T.; Zhou, Y.; Han, D.; Yin, S.-F.; Han, L.-B. Adv. Synth. Catal. 2014, 356, 765. For the semireduction of alkynes using a stoichiometric amount of $\left[\left(\mathrm{PPh}_{3}\right) \mathrm{CuH}\right]_{6}$, see: (e) Daeuble, J. F.; Mcgettigan, C.; Stryker, J. M. Tetrahedron Lett. 1990, 31, 2397.

(3) (a) Mahoney, W. S.; Stryker, J. M. J. Am. Chem. Soc. 1989, 111, 8818. (b) Chen, J.-X.; Daeuble, J. F.; Brestensky, D. M.; Stryker, J. M. Tetrahedron 2000, 56, 2153. (c) Chen, J.-X.; Daeuble, J. F. Tetrahedron 2000, 56, 2789. (d) Shimizu, H.; Igarashi, D.; Kuriyama, W.; Yusa, Y.; Sayo, N.; Saito, T. Org. Lett. 2007, 9, 1655. (e) Junge, K.; Wendt, B.; Addis, D.; Zhou, S.; Das, S.; Fleischer, S.; Beller, M. Chem. Eur. J. 2011, 17, 101.

(4) Sokol'skii, D. V.; Ualikhanova, A. Russ. J. Phys. Chem. 1977, 51, 886.

(5) (a) Brown, C. A.; Ahuja, V. K. J. Org. Chem. 1973, 38, 2226. (b) Brunet, J.-J.; Gallois, P.; Caubere, P. J. Org. Chem. 1980, 45, 1937. (c) Brunet, J.-J.; Caubere, P. J. Org. Chem. 1984, 49, 4058. (d) Choudary, B. M.; Sharma, G. V. M.; Bharathi, P. Angew. Chem., Int. Ed. Engl. 1989, 28, 465. (e) Choi, J.; Yoon, N. M. Tetrahedron Lett. 1996, 37, 1057. (f) Alonso, F.; Osante, I.; Yus, M. Tetrahedron 2007, 63, 93. (g) Mizugaki, T.; Murata, M.; Fukubayashi, S.; Mitsudome, T.; Jitsukawa, K.; Kaneda, K. Chem. Commun. 2008, 241.

(6) (a) Lindlar, H. Helv. Chim. Acta 1952, 35, 446. (b) Lindlar, H.; Dubuis, R. Org. Synth. 1966, 46, 89. (c) Marvell, E. N.; Li, T. Synthesis 1973, 457. (d) Rajaram, J.; Narula, A. P. S.; Chawla, H. P. S.; Dev, S. Tetrahedron 1983, 39, 2315.

(7) (a) Schrock, R. R.; Osborn, J. A. J. Am. Chem. Soc. 1976, 98, 2143. (b) Sodeoka, M.; Shibasaki, M. J. Org. Chem. 1985, 50, 1149. (c) van Laren, M. W.; Elsevier, C. J. Angew. Chem. Int. Ed. 1999, 38, 3715. (d) Sprengers, J. W.; Wassenaar, J.; Clement, N. D.; Cavell, K. J.; Elsevier, C. J. Angew. Chem. Int. Ed. 2005, 44, 2026. (e) Belger, C.; Neisius, N. M.; Plietker, B. Chem. Eur. J. 2010, 16, 12214. (f) La Pierre, H. S.; Arnold, J.; Toste, F. D. Angew. Chem. Int. Ed. 2011, 50, 3900. (g) Gianetti, T. L.; Tomson, N. C.; Arnold, J.; Bergman, R. G. J. Am. Chem. Soc. 2011, 133, 14904. (h) Chernichenko, K.; Madarász, Á.; Pápai, I.; Nieger, M.; Leskelä, M.; Repo, T. Nat. Chem. 2013, 5, 718. Transfer semihydrogenation of alkynes was also reported, see: (i) Trost, B. M.; Braslau, R. Tetrahedron Lett. 1989, 30, 4657. (j) Hauwert, P.; Maestri, G.; Sprengers, J. W.; Catellani, M.; Elsevier, C. J. Angew. Chem. Int. Ed. 2008, 47, 3223. (k) Hauwert, P.; Boerleider, R.; Warsink, S.; Weigand, J. J.; Elsevier, C. J. J. Am. Chem. Soc. 2010, 132, 16900. (1) Hua, J. L. R.; Liu, T. J. Org. Chem. 2010, 75, 2966. (m) Hua, J. L. R. Chem. Eur. J. 2011, 17, 8462. (n) Shen, R.; Chen, T.; Zhao, Y.; Qiu, R.; Zhou, Y.; Yin, S.; Wang, X.; Goto, M.; Han, L.-B. J. Am. Chem. Soc. 2011, 133, 17037.

(8) Churchill, M. R.; Kalra, K. Inorg. Chem. 1974, 13, 1065.

(9) General Procedure for the Copper-Catalyzed Semihydrogenation

In a glove box, $\left[\left(\mathrm{PPh}_{3}\right) \mathrm{CuCl}_{4}(7.2 \mathrm{mg}, 5.0 \mu \mathrm{mol})\right.$, toluene $(1.0$ $\mathrm{mL}$ ), LiOt-Bu (40 mg, $0.50 \mathrm{mmol}$ ), and $i-\operatorname{PrOH}(60 \mathrm{mg}, 1.0 \mathrm{mmol})$ were added to a vial in this order. After being stirred for $1 \mathrm{~min}$ at r.t., alkyne $\mathbf{1}(1.0 \mathrm{mmol})$ and toluene $(2.0 \mathrm{~mL})$ were added to the resulting mixture. The vial was placed in an autoclave, and the autoclave was taken out of the glove box. An $\mathrm{N}_{2}$ atmosphere in the autoclave was purged by positive pressure of $\mathrm{H}_{2}$. Then, the mixture was stirred at $100{ }^{\circ} \mathrm{C}$ for $3 \mathrm{~h}$ under $\mathrm{H}_{2}$ (5 atm). After being cooled to r.t., $\mathrm{H}_{2}$ was released, and the mixture was diluted with EtOAc. The conversion of alkynes was determined by GC analysis with $n$-tridecane as an internal standard. The resulting solution was filtered through a pad of silica gel, and the filtrate was concentrated. The residue was purified by medium-pressure column chromatography on silica gel to give $(Z)-\mathbf{2}$. 
Representative data:

(Z)-2d: The reaction of $\mathbf{1 d}(180 \mathrm{mg}, 1.0 \mathrm{mmol})$ at $60{ }^{\circ} \mathrm{C}$ followed by purification by MPLC ( $16 \mathrm{~g}$ of silica gel and Biotage ${ }^{\circledR}$ SNAP Ultra $10 \mathrm{~g} ; n$-hexane) gave the corresponding product ( $160 \mathrm{mg}$, $0.91 \mathrm{mmol}, 91 \%)$ as a mixture of $(Z)-\mathbf{2 d},{ }^{14 \mathrm{a}}(E)-\mathbf{2 d},{ }^{14 \mathrm{~b}}$ and $\mathbf{3 d}^{14 \mathrm{c}}$ $\left[(Z)-\mathbf{2 d} /(E)-\mathbf{2 d} / \mathbf{3 d}=95: 5:<1\right.$ determined by ${ }^{1} \mathrm{H}$ NMR analysis $]$ as a colorless oil; $R_{f}=0.53$ (hexane). ${ }^{1} \mathrm{H} \mathrm{NMR}\left(\mathrm{CDCl}_{3}, 400 \mathrm{MHz}\right): \delta=$ 7.28-7.16 (m, $10 \mathrm{H}), 6.60$ (s, $2 \mathrm{H}) ;{ }^{13} \mathrm{C}$ NMR $\left(\mathrm{CDCl}_{3}, 101 \mathrm{MHz}\right)$ : $\delta=137.2,130.2,128.8,128.2,127.1$. All the resonances of ${ }^{1} \mathrm{H}$ and ${ }^{13} \mathrm{C}$ NMR spectra were consistent with reported values. ${ }^{14 a}$ (Z)-2g: The reaction of $\mathbf{1 g}$ (79 $\mathrm{mg}, 0.30 \mathrm{mmol})$ at $80{ }^{\circ} \mathrm{C}$ in toluene $(0.80 \mathrm{~mL})$ followed by purification by MPLC (16 $\mathrm{g}$ of silica gel and Biotage ${ }^{\circledR}$ SNAP Ultra $10 \mathrm{~g} ; n$-hexane-EtOAc, 99:1 to $93: 7)$ gave the corresponding product $(Z)-2 \mathrm{~g}$ (42 $\mathrm{mg}, 0.16$ mmol, $52 \%$ ) as a pale yellow oil; $R_{f}=0.35$ ( $n$-hexane-EtOAc, 95:5). ${ }^{1} \mathrm{H}$ NMR $\left(\mathrm{CDCl}_{3}, 400 \mathrm{MHz}\right): \delta=7.90(\mathrm{~d}, J=8.5 \mathrm{~Hz}, 2 \mathrm{H})$, $7.30(\mathrm{~d}, J=8.5 \mathrm{~Hz}, 2 \mathrm{H}), 7.25-7.20(\mathrm{~m}, 5 \mathrm{H}), 6.71(\mathrm{~d}, J=12.2 \mathrm{~Hz}, 1$ $\mathrm{H}), 6.61(\mathrm{~d}, J=12.2 \mathrm{~Hz}, 1 \mathrm{H}), 5.24(\mathrm{sept}, J=6.1 \mathrm{~Hz}, 1 \mathrm{H}), 1.36$ (d, $J=6.1 \mathrm{~Hz}, 6 \mathrm{H}) ;{ }^{13} \mathrm{C}$ NMR $\left(\mathrm{CDCl}_{3}, 101 \mathrm{MHz}\right): \delta=165.9,141.8$,
136.7, 132.1, 129.4, 129.31, 129.28, 128.8, 128.7, 128.3, 127.4, 68.3, 21.9. HRMS-APCI (+): $m / z[M+H]^{+}$calcd for $\mathrm{C}_{18} \mathrm{H}_{19} \mathrm{O}_{2}$ : 267.1380; found: 267.1375

(10) $\left[\left(\mathrm{PPh}_{3}\right) \mathrm{CuH}\right]_{6}$ was synthesized from $\mathrm{Cu}(\mathrm{Ot}-\mathrm{Bu})$ and $\mathrm{Ph}_{3} \mathrm{P}$, see: (a) Goeden, G. V.; Caulton, K. G. J. Am. Chem. Soc. 1981, 103, 7354. For catalytic activation of $\mathrm{H}_{2}$ by copper salts, see (b) Halpern, J. J. Phys. Chem. 1959, 63, 398.

(11) syn-Addition of copper hydride across internal alkynes was reported, see: (a) Mankad, N. P.; Laitar, D. S.; Sadighi, J. P. Organometallics 2004, 23, 3369. (b) Fujihara, T.; Xu, T.; Semba, K.; Terao, J.; Tsuji, Y. Angew. Chem. Int. Ed. 2011, 50, 523.

(12) For a reference on protonation of an alkenyl copper with an alcohol, see ref. $2 a$.

(13) H-D exchange between copper hydride and alcohols was reported, see ref. 2b and: Lipshutz, B. H.; Servesko, J. M.; Taft, B. R. J. Am. Chem. Soc. 2004, 126, 8352.

(14) (a) Yan, M.; Jin, T.; Ishikawa, Y.; Minato, T.; Fujita, T.; Chen, L.-Y.; Bao, M.; Asao, N.; Chen, M.-W.; Yamamoto, Y. J. Am. Chem. Soc. 2012, 134, 17536. (b) Chen, Z.; Luo, M.; Wen, Y.; Luo, G.; Liu, L. Org. Lett. 2014, 16, 3020. (c) Kantam, M. L.; Kishore, R.; Yadav, J.; Sudhakar, M.; Venugopal, A. Adv. Synth. Catal. 2012, 354, 663. 